\title{
KANDUNGAN FITOKIMIA, KLOROFIL DAN BIOMASSA DAUN SEMBUNG (Blumea balsamifera) TERHADAP PENCAHAYAAN
}

\author{
Mamay Maslahat ${ }^{1)^{*}}$ dan Nia Yuliani ${ }^{2)}$ \\ 1)*Program Studi Kimia FMIPA Universitas Nusa Bangsa Bogor \\ ${ }^{2}$ Program Studi Biologi FMIPA Universitas Nusa Bangsa Bogor \\ Jl. KH Soleh Iskandar KM 4 Cimanggu Tanah Sareal, Bogor 16166 \\ *e-mail : maykulsum@yahoo.co.id
}

\begin{abstract}
The Influence of Lighting to The Phytochemistry, Chlorophyll and Biomass Content of Sembung Leaves (Blumea balsamifera)
\end{abstract}

\begin{abstract}
The secondary metabolite compounds on the sembung leaves are an active biopharmaceutical matter. Increase of the bio active production on field condition can be conducted by improving the plant biomass through shade and the period of lighting. The purpose of this research was to understand the influence of lighting to the phytochemical content, chlorophyll and biomass of sembung leaves that planted in the plantation area, Cogreg, Parung Bogor. The steps of this research consisted of the planting of sembung leaves in different lighting each treatment, the calculation of leaves biomass weight, the preparation of samples, the determination of the water level of samples, the phytochemical test of leaves samples and the analysis of chlorophyll content. Observation of the growth of sembung plants conducted periodically, starting from planting to the harvest. The results of statistical analysis of T test, on the observation of the growth of plants period I and period II showed that the average of the high and number of leaves differ significantly between plants that use shade and without shade (sig<0.05). The number of leaves sembung biomass planted without shade was heavier than planted with the shade. The water level of sembung leaves sample was 9,5\%. Total chlorophyll level of sembung leaves showed that the total chlorophyll level of the sembung leaves without shade was $15,6319 \mathrm{mg} / \mathrm{L}$, while the total chlorophyll level of the sembung leaves with shade was $20,0982 \mathrm{mg} / \mathrm{L}$. Based on the phytochemical test showed that the secondary metabolite compound which contained in both of sembung leaves sample grown using shade or without shade did not differ significantly to flavonoid, saponin, glycosides, alkaloids and terpenoid.
\end{abstract}

Keywords: Blumea balsamifera, phytochemistry, chlorophyll, lighting

\begin{abstract}
ABSTRAK
Senyawa metabolit sekunder yang terdapat pada daun sembung merupakan bahan aktif biofarmaka. Pemacuan produksi bioaktif tanaman pada kondisi lapang dapat dilakukan dengan meningkatkan biomassa tanaman melalui naungan dan periode pencahayaan. Penelitian ini bertujuan untuk mengetahui pengaruh pencahayaan terhadap kandungan fitokimia, klorofil dan biomassa daun sembung yang ditanam di areal perkebunan Cogreg Parung Bogor. Tahapan penelitian terdiri atas penanaman dengan perlakuan pencahayaan yang berbeda pada setiap petak terpisah, penghitungan bobot biomassa daun, preparasi simplisia, penetapan kadar air simplisia, uji fitokimia simplisia daun dan analisis kandungan klorofil. Pengamatan pertumbuhan tanaman dilakukan secara periodikal dari mulai tanam hingga panen. Hasil statistik Uji T pada pengamatan pertumbuhan tanaman periode I \& II menunjukkan bahwa rata-rata tinggi sembung dan jumlah daun berbeda secara signifikan antara tanaman yang menggunakan naungan dan tanpa naungan dengan nilai sig $<0,05$. Jumlah biomassa daun sembung yang ditanam tanpa naungan menghasilkan berat lebih besar dibandingkan dengan naungan. Kadar air simplisia daun sembung sebesar 9,5\%. Kadar klorofil total daun sembung tanpa naungan dan dengan naungan berturut-turut adalah 15,6319 mg/L dan 20,0982 mg/L. Kandungan senyawa metabolit sekunder simplisia daun sembung adalah flavonoid, saponin, glikosida, alkaloid, dan terpenoid.
\end{abstract}

Kata kunci : Blumea balsamifera, fitokimia, klorofil, pencahayaan 


\section{PENDAHULUAN}

Pengembangan biofarmaka di Indonesia belum mendapatkan prioritas utama. Upaya-upaya pengembangan biofarmaka, termasuk penelitian, dilakukan oleh beberapa institusi namun tidak fokus dan tidak terintegrasi, sehingga sulit untuk menghasilkan produk yang siap dijual dan kurang efektif baik dilihat dari pemecahan masalah yang dihadapi maupun dalam mengisi peluang yang ada. Sementara itu, negara-negara lain telah menempatkan pembangunan biofarmaka pada prioritas yang tinggi dan sebagai salah satu tumpuan harapan dalam pembangunan ekonomi dan kesejahteraan rakyatnya. Seperti Malaysia, mempunyai visi peng-hasil rempah dan biofarmaka terbesar kedua setelah Cina. Apabila tidak dilakukan perubahan yang mendasar dalam hal kebijakan pengembangan biofarmaka, dimulai dari hulu sampai hilir (mulai dari benih, teknologi budidaya, persiapan ba-han baku, industri pengolahan, pengujian keamanan, toksisitas, klinis, sampai dengan promosi penggunaan dan pemasaran), maka dalam beberapa tahun mendatang niscaya Indonesia hanya akan menjadi pengekspor bahan baku saja. Itupun, kalau bahan baku dari Indonesia mampu bersaing dalam hal mutu, ketepatan waktu, ketepatan jumlah dan harga dengan produsen dari negara lain.

Seiring dengan pemanfaatan tanaman obat terutama dalam bidang kesehatan yang semakin berkembang, maka kualitas/ mutu menjadi salah satu prasyarat yang tidak dapat diabaikan. Penggunaan ta-naman obat dalam dunia kesehatan baik sebagai promotif, preventif, kuratif, rehabilitative, dan paliatif tentu memiliki persyaratanpersyaratan yang harus dipenuhi. Beberapa farmakope termasuk Farmakope Herbal Indonesia menjadi salah satu acuan dalam melakukan standarisasi tanaman atau bentuk sediaan ekstrak guna menjamin kualitasnya. Standardisasi merupakan cara untuk menjaga kualitas tanaman obat atau produk sediaannya meliputi aspek fisik, kimia dan biologi. Aspek farmakologis ditentukan dengan adanya senyawa atau golongan senyawa yang terkandung dalam tanaman obat atau produknya yang di-tentukan baik secara kualitatif ataupun kuantitatif.

Daun sembung (Blumea) merupakan salah satu tanaman biofarmaka yang memiliki banyak khasiat. Masyarakat Indonesia memanfaatkan daun sembung untuk mengatasi influenza, rematik, nyeri haid, haid tidak teratur, demam, asma, batuk, bronchitis, perut kembung, diare, dan diabetes (Dalimartha, 1999).

Senyawa metabolit sekunder yang terdapat pada daun sembung merupakan bahan aktif biofarmaka. Metabolit sekunder terdiri atas senyawa flavonoid, alkaloid, tanin, terpenoid dan saponin. Flavonoid telah dibuktikan dapat menghambat pertumbuhan sel-sel kanker pada manusia (Lamson dan Brignall, 2000) Senyawa flavonoid dan polifenolat bersifat antioksidan, antidiabetik, antikanker, antiseptik, dan anti inflamasi (Sudewo, 2005). Flavonoid merupakan senyawa yang mengandung $\mathrm{C}_{15}$ yang terdiri atas dua inti fenolat yang dihubungkan dengan tiga satuan karbon. Cincin A mempunyai karakteristik bentuk hidroksilasi floroglusinol atau resorsinol, dan cincin B biasanya 4-,3,4,atau 3,4,5-terhidroksilasi.

(Sastrohamidjodjo, 1995).

Pemacuan produksi bioaktif tanaman (termasuk kandungan flavonoid) pada kondisi lapang dapat dilakukan dengan meningkatkan biomassa tanaman melalui naungan dan periode pencahayaan. Pada beberapa penelitian sebelumnya telah diketahui bahwa pemberian naungan dapat mempengaruhi kandungan bioaktif ta-naman. Oleh karena itu pada penelitian ini akan dikaji pengaruh pencahayaan terhadap kandungan flavonoid dan biomassa dari daun sembung yang ditanam di areal Perkebunan Cogreg.

Penelitian ini bertujuan untuk mengetahui pengaruh pencahayaan 
terhadap kandungan fitokimia, klorofil dan biomassa daun sembung yang ditanam di areal perkebunan Cogreg Parung Bogor.

\section{BAHAN DAN METODE}

\section{Alat dan Bahan}

Peralatan yang digunakan adalah oven, grinder, mesh 16, timbangan analitik (Mettler Toledo XS205 DU), rotary evaporator (Ika), peralatan gelas, perlengkapan refluks, kapas (Sariayu), kertas saring berabu, shaker (Heidolph Promax 1020), Rotary Eva Porator, spektrofotometer UV-Visible (Shimadzu 1601).

Bahan-bahan yang digunakan antara lain, daun sembung, paranet 25 dan 50\%, etanol 95\% (Merck), ammonia 25\% (Merck), kloroform (Mallinkrodt), $\mathrm{HCl} 37 \%$ (Merck), pereaksi Liebermann-Burchard, serbuk magnesium, amilalkohol, $\mathrm{FeCl} 31 \%$, dietileter (Merck), heksametilentetramin 0,5\%, aseton (Merck), etilasetat (Merck), akuades, $\mathrm{AlCl} 32 \%$, asam asetat glasial $5 \%$ dalam metanol, kuersetin (Sigma),

\section{Metode Penelitian}

Rangkaian penelitian ini dimulai dengan melakukan penanaman tanaman daun sembung di areal Perkebunan Cogreg dengan perlakuan pencahayaan yang berbeda pada setiap petak terpisah. Pada hasil panen dilakukan penghitungan bobot biomassa daun sembung. Penelitian dilanjutkan dengan determinasi tanaman, preparasi simplisia dan uji kualitatif flavonoid simplisia, penetapan kadar air simplisia, pembuatan ekstrak daun sembung dengan etanol 95\% dan uji kualitatif flavonoid dan penentuan flavonoid total pada hasil ekstrak.

\section{Penanaman Tanaman daun Sembung}

Percobaan disusun berdasarkan rancangan petak terpisah (Split Plot
Design). Perlakuan cahaya yang digunakan adalah : $100 \%$ cahaya selama 2 bulan masa tanam, naungan 50\% selama 2 bulan masa tanam, dan naungan $25 \%$ selama 2 bulan masa tanam.

\section{Penghitungan Bobot Biomassa Total Daun Sembung}

Daun sembung dipanen dari seluruh tanaman dan dikelompokkan sesuai dengan perlakuan pencahayaan. Dilakukan penimbangan terhadap seluruh daun sembung yang dipanen.

\section{Determinasi Tanaman}

Determinasi tanaman dilakukan untuk memastikan kebenaran simplisia yang akan digunakan dalam penelitian. Determinasi dilakukan di Pusat Penelitian Biologi-Lembaga Ilmu Pengetahuan Indonesia (LIPI) di Cibinong, Bogor.

\section{Preparasi Simplisia}

\section{a. Pengumpulan Sampel}

Daun sembung segar dibersihkan dari kotoran-kotoran yang menempel (sortasi basah), dicuci dengan air hingga bersih, kemudian ditiriskan untuk membebaskan daun dari sisa air cucian. Daun yang telah bersih dikeringkan dalam oven pada suhu $50^{\circ} \mathrm{C}$ selama 24 jam, kemudian daun yang telah kering dibersihkan kembali dari kotoran yang mungkin tidak hilang pada saat pencucian (sortasi kering). Selanjutnya daun kering digiling sehingga menjadi simplisia serbuk lalu diayak dengan mesh 16. Simplisia disimpan dalam wadah bersih dan ditutup rapat (Depkes, 1985).

\section{b. Penetapan Kadar Air Simplisia}

Penetapan kadar air simplisia dilakukan dengan metode pemanasan menggunakan oven pada suhu $110^{\circ} \mathrm{C}$, dan ditimbang hingga bobot tetap. 


\section{Uji Fitokimia Simplisia Daun Sembung}

Analisis fitokimia dilakukan berdasarkan Harborne (1987). Identifikasi yang dilakukan adalah uji alkaloid, tannin, flavonoid, saponin, steroid, dan triterpenoid.Analisis fitokimia ini adalah untuk menentukan ada atau tidaknya kandungan metabolit sekunder yang memiliki potensi sebagai bioaktif.

\section{Uji Klorofil}

1 gram daun sembung ditimbang kemudian diekstrak dengan pelarut etanol $96 \%$. Larutan ekstrak disaring dan diambil filtratnya. Filtrat dimasukkan ke dalam labu takar $100 \mathrm{ml}$. Kemudian ditambahkan dengan pelarut yang sama sehingga larutan menjadi 100 ml. Filtrat diukur dengan Spektrofotometer pada $\lambda 649$ dan $\lambda 665$.

Perhitungan kadar klorofil pada daun $(\mathrm{mg} / \mathrm{L})$ :

$20($ Abs pada $\lambda 649)+6,1$ (Abs pada $\lambda$ 665)

\section{HASIL DAN PEMBAHASAN}

\section{Kondisi Tanah Perkebunan Cogreg}

Pada penelitian ini dilakukan pula analisis tanah Kebun Cogreg untuk mengetahui karakteristiknya sebelum dilakukan penanaman Tanaman Sembung. Berdasarkan Kriteria Penilaian Sifat Kimia Tanah (Pusat Penelitian Tanah,
1983) terhadap hasil analisis Tanah Cogreg diketahui bahwa $\mathrm{pH}$ tanah bersifat masam dengan derajat $\mathrm{pH}$ 4,6 dan tekstur tanah termasuk liat. Kandungan organik tanah termasuk ke dalam golongan sangat tinggi sedangkan kandungan Nitrogen dan Kalium termasuk golongan sedang. Kandungan Posfor dan Alumunium sangat rendah sedangkan kandungan $\mathrm{CaCO} 3$ rendah. Hasil analisis tanah Cogreg se-cara keseluruhan ditampilkan pada Tabel 1 . Berdasarkan hal ini, maka terhadap Tanah Cogreg diperlukan adanya proses pemupukan untuk meningkatkan kandungan Posfor, Kalium, Nitrogen dan Ca.

Tabel 1. Karakteristik Tanah Cogreg Parung

\begin{tabular}{llc}
\hline No & \multicolumn{1}{c}{ Parameter } & Hasil analisis \\
\hline 1 & Kadar Air (\%) & 11,45 \\
2 & pH H $\mathrm{H}_{2} \mathrm{O}$ & 4,60 \\
& pH KCl & 4,23 \\
3 & N Total (\%) & 0,437 \\
4 & C Organik (\%) & 5,1093 \\
5 & B Organik (\%) & 8,8092 \\
6 & Kalium(\%) & 0,57 \\
7 & Posfor (\%) & 0,25 \\
8 & Tekstur & \\
& Debu (\%) & 16,02 \\
& Liat (\%) & 76,67 \\
& Pasir (\%) & 7,30 \\
9 & Al-dd (\%) & 0,0014 \\
10 & Hidrogen & 2,86 \\
& tertukar (\%) & \\
11 & CaCO3 (\%) & 5,72 \\
\hline
\end{tabular}
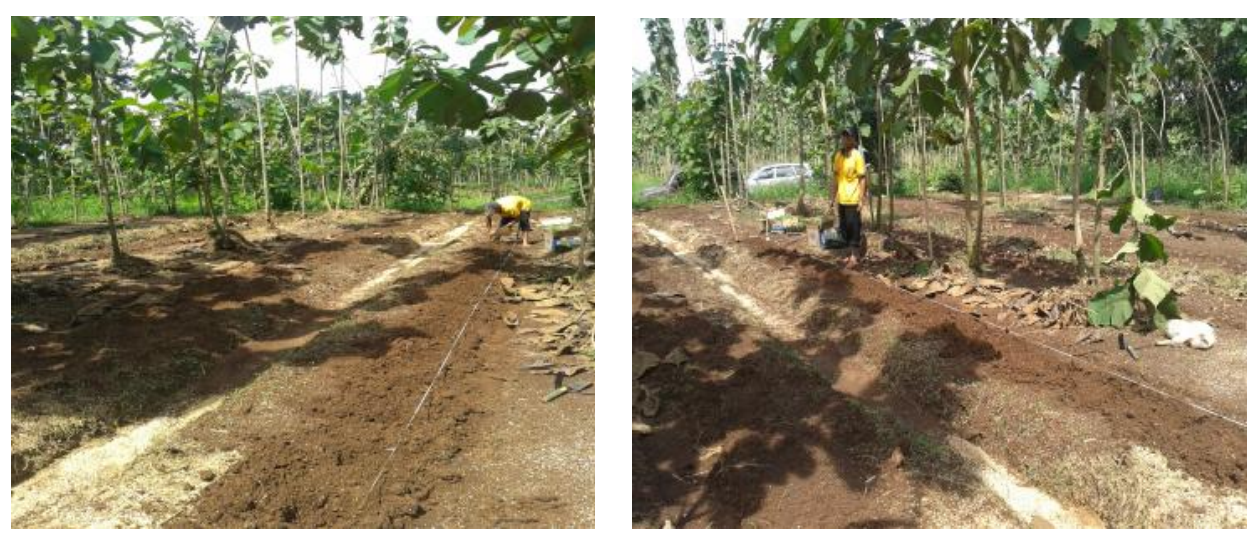

Gambar 1. Petak untuk Penanaman Daun Sembung 


\section{Pengolahan \& persiapan lahan}

Lahan yang disiapkan adalah lahan yang tersedia di antara trubusan tanaman JUN yang telah tumbuh. Dibuat petakpetak tanah yang terdiri atas dua kelompok yaitu petak untuk tanaman tanpa naungan, dan petak untuk tanaman dengan naungan menggunakan para net.
1. Penanaman tanaman sembung

Tanaman sembung ditanam sebanyak 2 petak dengan masing-masing petak berjumlah 28 tanaman. Petak pertama mendapatkan paparan sinar matahari $100 \%$, sedangkan petak yang kedua paparan matahari terhalang oleh para net ukuran $60 \%$.
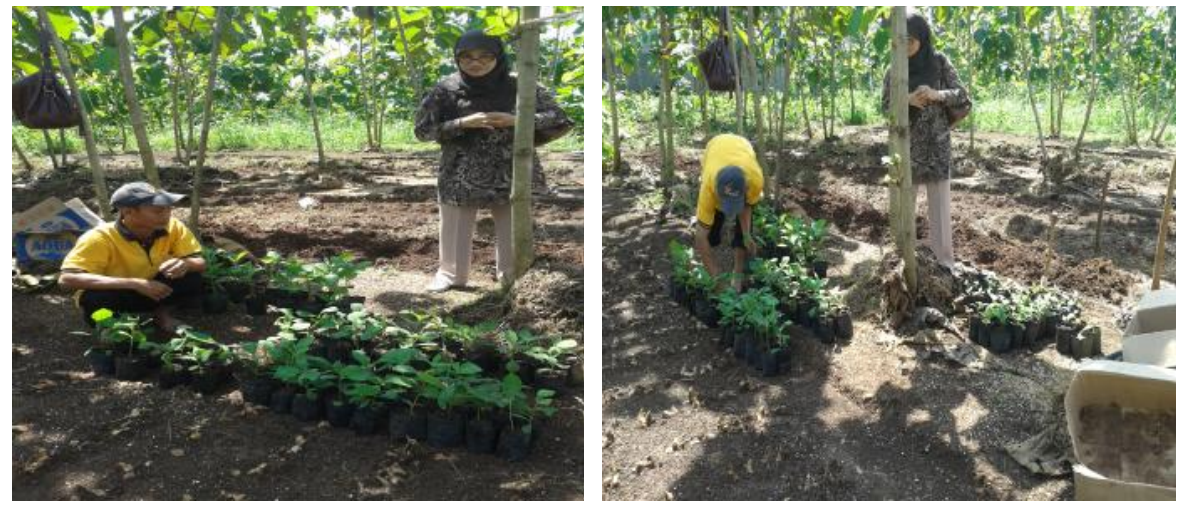

Gambar 2. Pemilihan Bibit Tanaman Daun Sembung
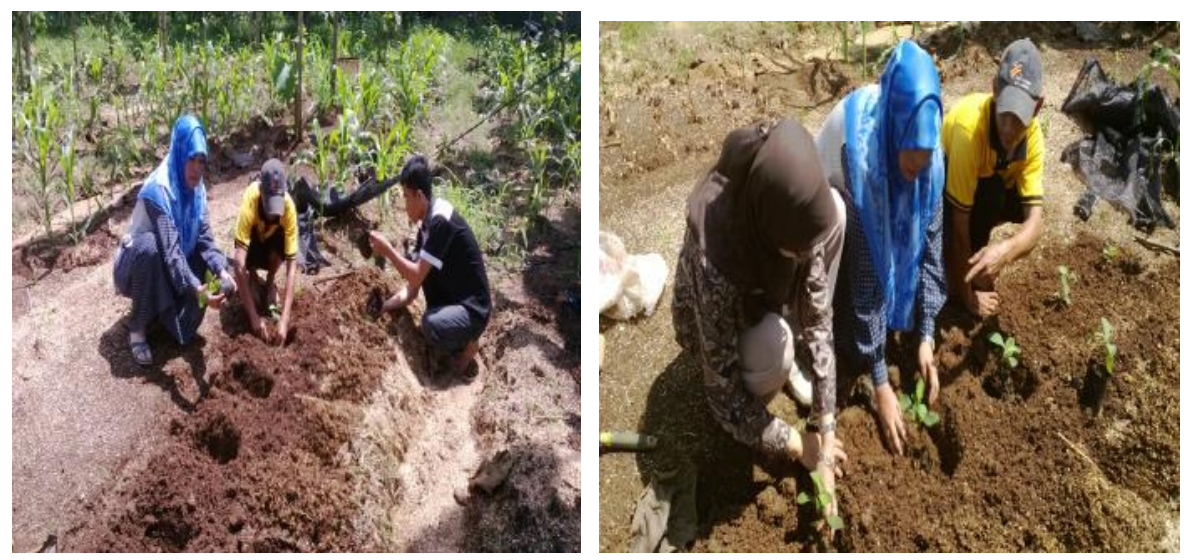

Gambar 3. Proses Penanaman Daun Sembung 



Gambar 4. Petak Tanaman Daun Sembung dengan Naungan Para Net dan Tanpa Naungan
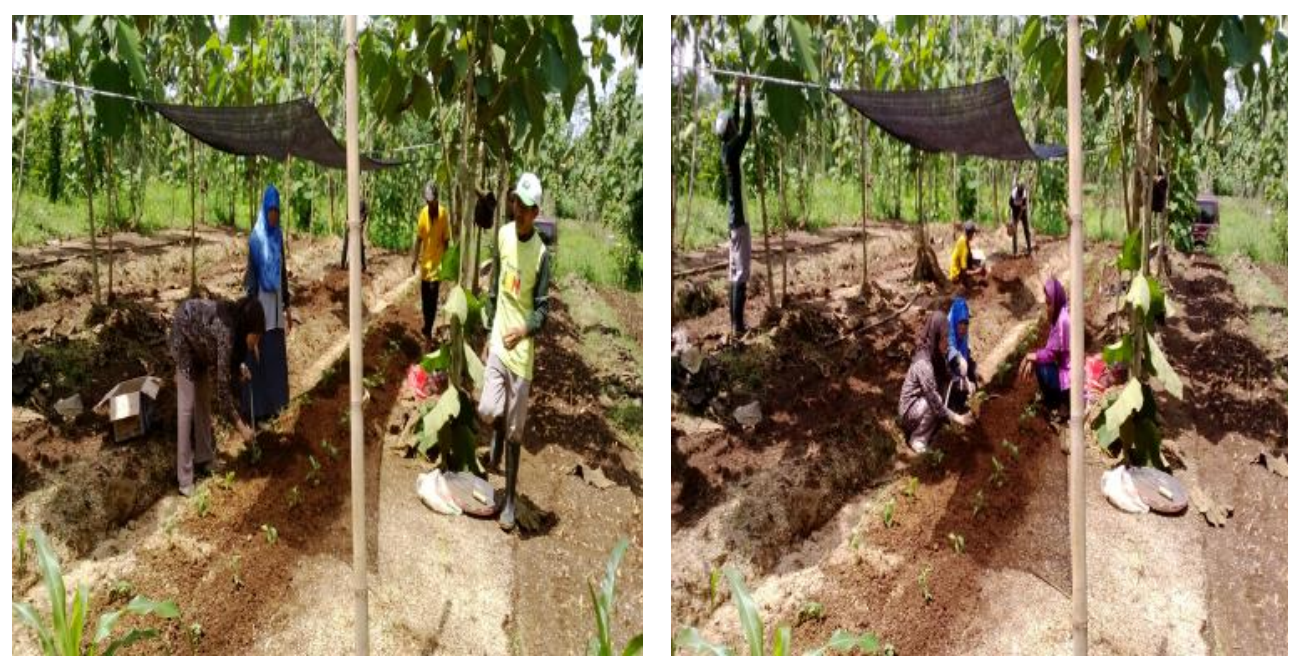

Gambar 5. Pengamatan Tinggi Tanaman dan Jumlah Daun Sembung Saat Penanaman

2. Pengamatan pertumbuhan tanaman sembung

Bibit tanaman sembung yang ditanam berusia 2 bulan dengan rata-rata tinggi tanaman $12,88 \mathrm{~cm}$ dan jumlah daun 7daun untuk petak dengan naungan para net, sedangkan untuk petak tanpa naungan, rata-rata tinggi tanaman adalah $12,02 \mathrm{~cm}$ dan jumlah daun 7 daun.
Data pengamatan pada periode I ( 3 minggu setelah tanam)

Pengamatan pertumbuhan tanaman sembung dilakukan secara periodikal dari mulai tanam hingga panen dengan periode 3 minggu sekali. Hasil statistik Uji $\mathrm{T}$ pada pengamatan pertumbuhan tanaman periode I menunjukkan bahwa rata-rata tinggi sembung dan jumlah daun berbeda secara signifikan antara tanaman yang menggunakan naungan dan tanpa naungan karena sig $<0,05$. Data lengkap uji statistik disajikan pada Lampiran 
Tabel 2. Pengamatan Pertumbuhan Tanaman Sembung Periode I

\begin{tabular}{|c|c|c|c|c|}
\hline \multicolumn{3}{|c|}{ Naungan } & \multicolumn{2}{|c|}{ Tanpa naungan } \\
\hline No & $\begin{array}{l}\text { Tinggi } \\
\text { Tanaman }(\mathrm{cm})\end{array}$ & $\begin{array}{l}\text { Jumlah } \\
\text { Daun } \\
\text { (buah) }\end{array}$ & $\begin{array}{l}\text { Tinggi } \\
\text { Tanaman }(\mathrm{cm})\end{array}$ & $\begin{array}{l}\text { Jumlah } \\
\text { daun (buah) }\end{array}$ \\
\hline 1 & 7 & 8 & 16 & 8 \\
\hline 2 & 8 & 6 & 18 & 8 \\
\hline 3 & 10 & 11 & 10 & 5 \\
\hline 4 & 14 & 13 & 16 & 8 \\
\hline 5 & 17 & 22 & 22 & 10 \\
\hline 6 & 13 & 10 & 17 & 9 \\
\hline 7 & 20 & 13 & 19 & 8 \\
\hline 8 & 16 & 10 & 18 & 9 \\
\hline 9 & 16 & 11 & 20 & 9 \\
\hline 10 & 19 & 10 & 19 & 9 \\
\hline 11 & 16 & 10 & 26 & 11 \\
\hline 12 & 17 & 10 & 19 & 11 \\
\hline 13 & 11 & 10 & 17 & 10 \\
\hline 14 & 10 & 9 & 15 & 10 \\
\hline 15 & 12 & 10 & 14 & 7 \\
\hline 16 & 10 & 7 & 12 & 6 \\
\hline 17 & 24 & 12 & 27 & 10 \\
\hline 18 & 14 & 12 & 14 & 8 \\
\hline 19 & 20 & 9 & 22 & 10 \\
\hline 20 & 20 & 10 & 18 & 10 \\
\hline 21 & 15 & 11 & 18 & 4 \\
\hline 22 & 16 & 9 & 22 & 8 \\
\hline 23 & 12 & 10 & 20 & 9 \\
\hline 24 & 20 & 11 & 22 & 7 \\
\hline 25 & 15 & 10 & 18 & 8 \\
\hline 26 & 12 & 9 & 18 & 8 \\
\hline 27 & 14 & 8 & 16 & 7 \\
\hline 28 & 14 & 10 & 18 & 8 \\
\hline Rataan & 14,71 & 10,39 & 18,25 & 8,39 \\
\hline
\end{tabular}

Hasil pengamatan periode I menunjukan bahwa jumlah daun dan warna daun pada petak yang ternaungi para net berjumlah lebih banyak dan warnya lebih hijau dibandingkan dengan tanpa naungan. 

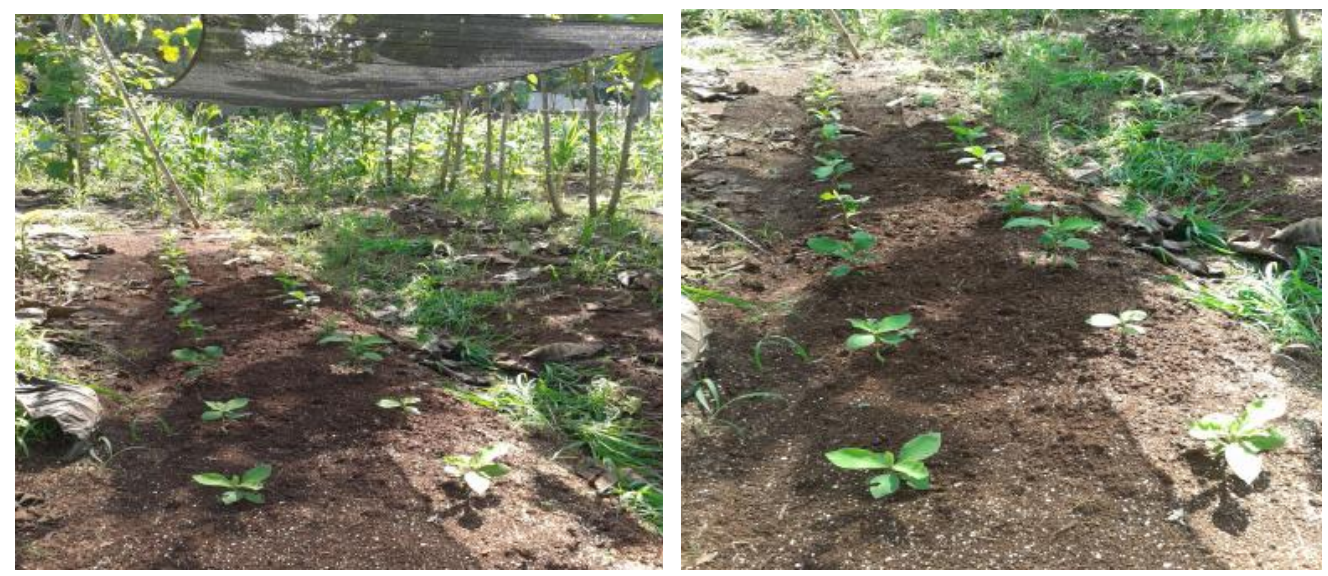

Gambar 6. Pengamatan Tanaman Periode I (Usia 3 Minggu Masa Tanam)

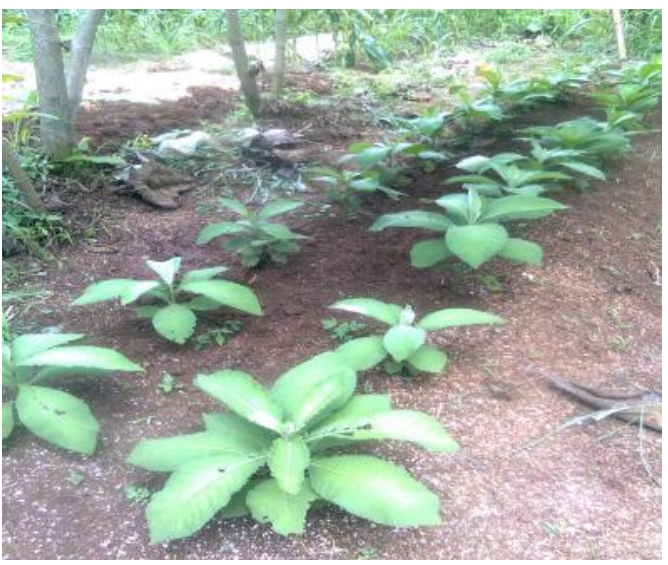

(A)

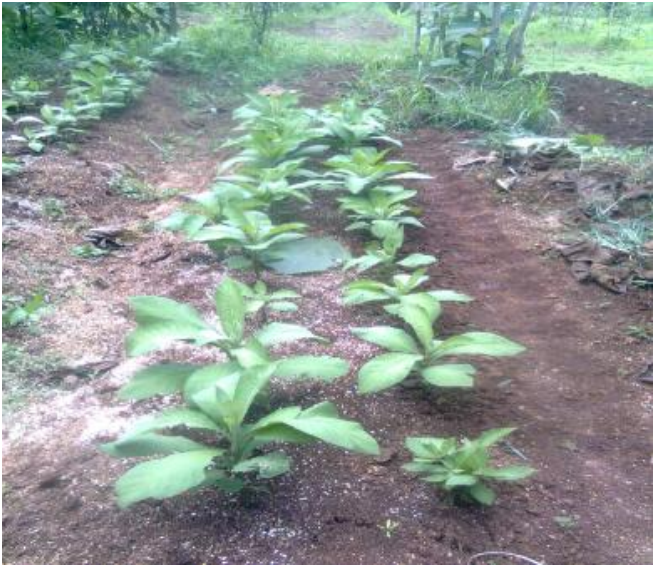

(B)

Gambar 7. Pengamatan Tanaman Periode II (Usia 6 Minggu Masa Tanam) (A) Naungan Para Net, (B) Tanpa Naungan

\section{Data Pengamatan pada Periode II ( 6 Minggu setelah Tanam)}

Secara umum teramati bahwa tanaman yang menggunakan naungan memiliki warna daun lebih hijau dan ukuran daun lebih besar. Pengamatan pertumbuhan tanaman daun sembung periode II menunjukan pada tanaman no 5 yang di bawah naungan net memiliki jumlah daun yang paling banyak dengan jumlah 45 buah, dibanding dengan tanaman lainnya, akan tetapi ukuran daun lebih kecil-kecil. Hal serupa terjadi juga pada tanaman No.1 tanpa naungan memiliki jumlah daun 47. Kondisi dari kedua tanaman ini yang teramati adalah tanaman bercabang-cabang. Data pengamatan pertumbuhan tanaman sembung periode II ditunjukkan oleh Tabel 3. 
Tabel 3. Pengamatan Pertumbuhan Tanaman Sembung Periode II

\begin{tabular}{|c|c|c|c|c|}
\hline \multicolumn{3}{|c|}{ Naungan } & \multicolumn{2}{|c|}{ Tanpa naungan } \\
\hline No & $\begin{array}{l}\text { Tinggi } \\
\text { Tanaman }(\mathrm{cm})\end{array}$ & $\begin{array}{l}\text { Jumlah } \\
\text { Daun(buah) }\end{array}$ & $\begin{array}{l}\text { Tinggi } \\
\text { Tanaman }(\mathrm{cm})\end{array}$ & $\begin{array}{l}\text { Jumlah } \\
\text { daun(buah) }\end{array}$ \\
\hline 1 & 22 & 14 & 22 & 47 \\
\hline 2 & 14.5 & 9 & 27 & 14 \\
\hline 3 & 31 & 18 & 23 & 13 \\
\hline 4 & 31 & 19 & 23 & 15 \\
\hline 5 & 21 & 45 & 30 & 15 \\
\hline 6 & 34 & 16 & 26 & 13 \\
\hline 7 & 45 & 18 & 35 & 21 \\
\hline 8 & 34 & 17 & 32.5 & 17 \\
\hline 9 & 39 & 16 & 22 & 9 \\
\hline 10 & 33 & 15 & 41 & 18 \\
\hline 11 & 32 & 12 & 34.5 & 15 \\
\hline 12 & 28 & 20 & 34 & 16 \\
\hline 13 & 25 & 13 & 33.5 & 18 \\
\hline 14 & 29.5 & 13 & 29 & 20 \\
\hline 15 & 30 & 17 & 29 & 19 \\
\hline 16 & 22 & 12 & 32 & 18 \\
\hline 17 & 42 & 18 & 32 & 19 \\
\hline 18 & 36.5 & 20 & 45 & 21 \\
\hline 19 & 34 & 17 & 38.5 & 18 \\
\hline 20 & 34.5 & 23 & 33 & 21 \\
\hline 21 & 33 & 18 & 33.5 & 15 \\
\hline 22 & 20 & 14 & 29.5 & 18 \\
\hline 23 & 30 & 20 & 30.5 & 16 \\
\hline 24 & 43.5 & 17 & 33.5 & 19 \\
\hline 25 & 39 & 17 & 32 & 22 \\
\hline 26 & 27.5 & 14 & 13.5 & 11 \\
\hline 27 & 22 & 12 & 34 & 19 \\
\hline 28 & 30.5 & 15 & 33 & 18 \\
\hline Rataan & 28,02 & 17,11 & 30,77 & 19,43 \\
\hline
\end{tabular}

Hasil statistik Uji $\mathrm{T}$ pada pengamatan pertumbuhan tanaman periode II menunjukkan bahwa rata-rata tinggi sembung dan jumlah daun tidak berbeda nyata antara tanaman yang menggunakan naungan dan tanpa naungan karena sig $<0,05$.

Tanaman No 22 dan 27 di bawah naungan net, terserang oleh hama kutu putih sehingga memiliki daun dengan bentuk keriting dan tanaman kerdil. 

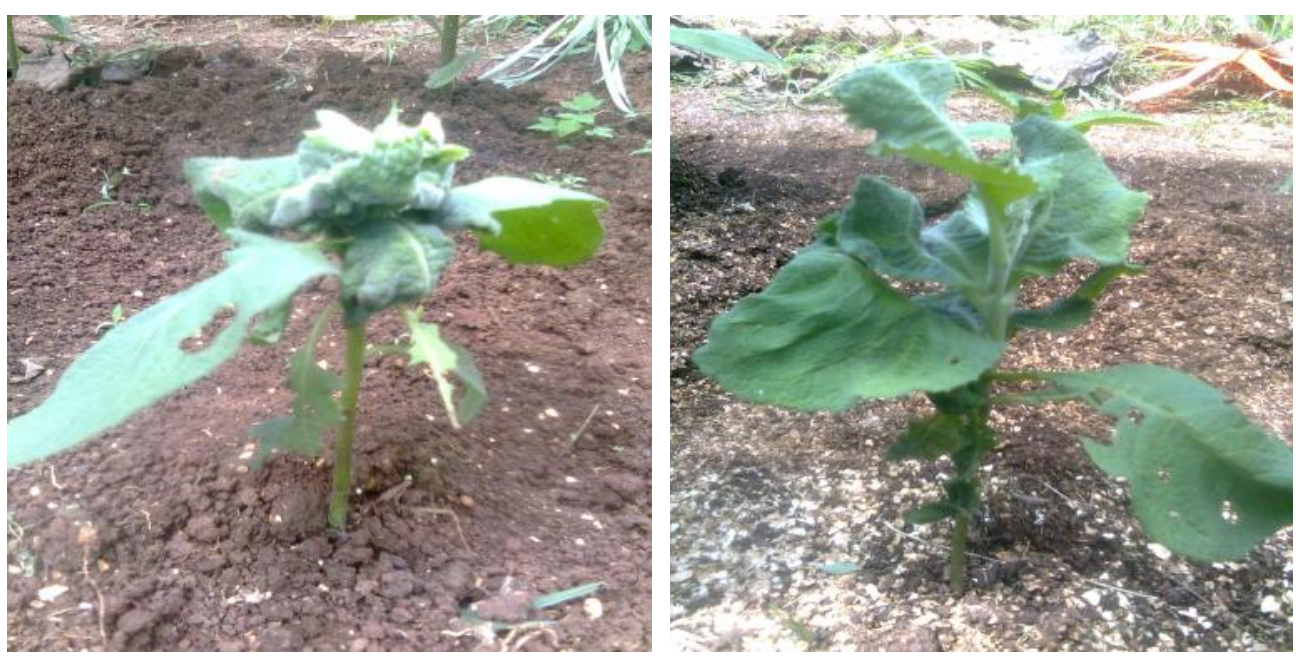

Gambar 8. Tanaman Terserang Hama Kutu Putih

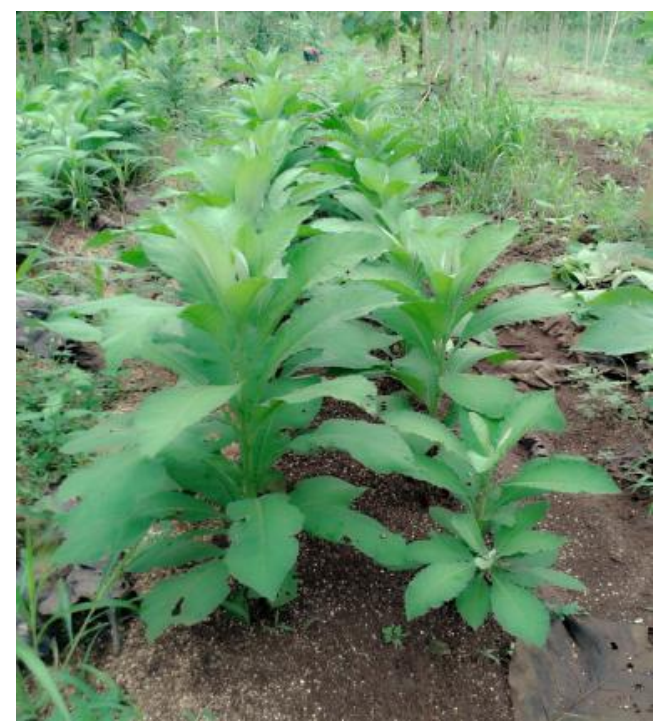

(A)

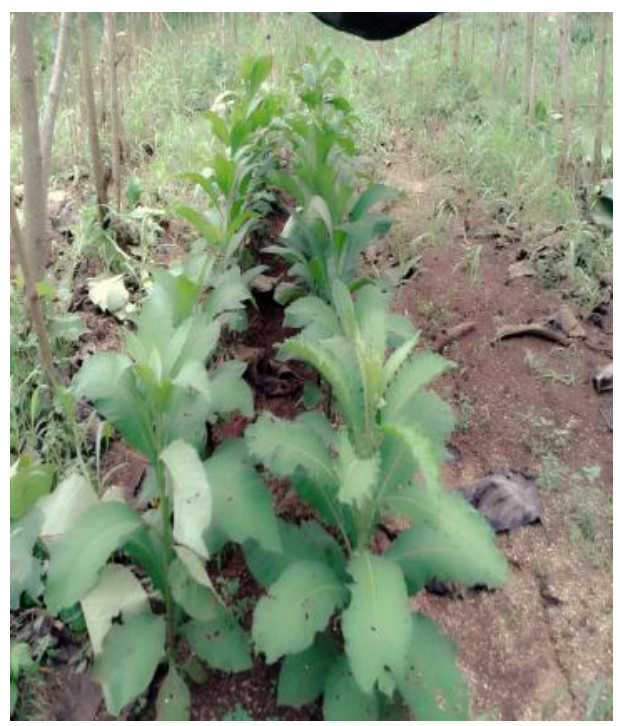

(B)

Gambar 9. Pengamatan Tanaman Periode III (Usia 9 Minggu Masa Tanam) (A) Tanpa Naungan, (B) Tanpa Naungan Para Net

\section{Pengamatan Pertumbuhan Tanaman Sembung Periode III}

Pengamatan dilakukan setelah 9 minggu masa tanam. Hasil pengamatan disajikan pada Gambar 9 dan Tabel 4. 
Tabel 4. Pengamatan Pertumbuhan Tanaman Sembung Periode III

\begin{tabular}{|c|c|c|c|c|}
\hline \multicolumn{3}{|c|}{ Naungan } & \multicolumn{2}{|c|}{ Tanpa naungan } \\
\hline No & $\begin{array}{l}\text { Tinggi } \\
\text { Tanaman }(\mathrm{cm})\end{array}$ & $\begin{array}{l}\text { Jumlah } \\
\text { Daun } \\
\text { (buah) }\end{array}$ & $\begin{array}{l}\text { Tinggi } \\
\text { Tanaman }(\mathrm{cm})\end{array}$ & $\begin{array}{l}\text { Jumlah } \\
\text { daun (buah) }\end{array}$ \\
\hline 1 & 55,5 & 23 & 42 & 58 \\
\hline 2 & 25,5 & 14 & 63 & 22 \\
\hline 3 & 67 & 29 & 59,5 & 21 \\
\hline 4 & 62,5 & 23 & 54 & 18 \\
\hline 5 & 49 & 61 & 63 & 21 \\
\hline 6 & 69 & 23 & 59 & 17 \\
\hline 7 & 87 & 31 & 78.5 & 27 \\
\hline 8 & 71 & 22 & 72 & 28 \\
\hline 9 & 71 & 24 & 44 & 13 \\
\hline 10 & 67 & 22 & 33.5 & 27 \\
\hline 11 & 53 & 19 & 75 & 25 \\
\hline 12 & 50,5 & 23 & 77 & 24 \\
\hline 13 & 60 & 20 & 84 & 30 \\
\hline 14 & 62 & 23 & 85 & 31 \\
\hline 15 & 65 & 26 & 77 & 28 \\
\hline 16 & 53,5 & 18 & 74 & 26 \\
\hline 17 & 74,5 & 25 & 72 & 26 \\
\hline 18 & 65,5 & 23 & 95 & 30 \\
\hline 19 & 69 & 22 & 85 & 26 \\
\hline 20 & 63 & 23 & 84 & 31 \\
\hline 21 & 70 & 26 & 81 & 26 \\
\hline 22 & 23 & - & 72 & 26 \\
\hline 23 & 63 & 28 & 76 & 24 \\
\hline 24 & 80 & 25 & 60 & 26 \\
\hline 25 & 87 & 32 & 75 & 32 \\
\hline 26 & 62 & 21 & 41 & 18 \\
\hline 27 & 48,5 & 21 & 86 & 30 \\
\hline 28 & 74 & 28 & 83 & 30 \\
\hline Rataan & 62.43 & 25,00 & 69.66 & 26.46 \\
\hline
\end{tabular}

Hasil statistik Uji $\mathrm{T}$ pada pengamatan pertumbuhan tanaman periode III menunjukkan bahwa rata-rata tinggi sembung dan jumlah daun tidak berbeda nyata antara tanaman yang menggunakan naungan dan tanpa naungan karena sig $<0,05$.
Penghitungan Jumlah Biomassa daun Sembung

Dilihat dari jumlah biomassa yang dihasilkan, diketahui bahwa biomassa daun sembung yang ditanam tanpa naungan menghasilkan berat lebih besar dibandingkan dengan naungan. Jumlah 
Biomassa daun sembung tanpa naungan adalah $4,85 \mathrm{Kg}$ berat basah, sedangkan jumlah biomassa daun sembung dengan naungan sebesar $4,15 \mathrm{Kg}$ berat basah.

\section{Penetapan Kadar Air Simplisia}

Kadar air ditetapkan dengan cara gravimetri, yaitu diperoleh dengan cara menghitung bobot bahan sebelum dan sesudah dikeringkan pada temperatur di atas titik didih air, sehingga diharapkan semua air akan menguap pada suhu tersebut dan pada periode waktu tertentu. Kadar air simplisia daun sembung yang telah dikeringkan pada suhu $70^{\circ} \mathrm{C}$ selama 5 hari adalah $9,5 \%$. Menurut Depkes RI (1985), standar kadar air untuk simplisia adalah kurang dari $10 \%$. Kadar air yang bagus untuk simplisia adalah 6-7\%. Jika kurang dari nilai tersebut, kemungkinan zat aktif dalam simplisia tersebut telah hilang, jika lebih dari 10\%, simplisia akan mudah ditumbuhi jamur.

\section{Penetapan Kandungan klorofil daun sembung}

Hasil analisis kadar klorofil total daun sembung dengan metode spektrofotometri menunjukkan bahwa Kadar klorofil total daun sembung tanpa naungan adalah $15,6319 \mathrm{mg} / \mathrm{L}$, sedangkan kadar klorofil total daun sembung dengan naungan sebesar 20,0982 mg/L. Kadar klorofil pada naungan lebih tinggi dibandingkan dengan tanpa naungan. Hal ini disebabkan karena kedua tanaman tadi memperoleh intensitas cahaya yang berbeda. Intensitas cahaya tinggi, laju fotosintesis bisa mencapai maksimum dan menghasilkan banyak karbohidrat.

Molekul klorofil tersusun atas 4 cincin pirol dengan $\mathrm{Mg}$ sebagai inti. Pada klorofil terdapat rangkaian yang disebut fitil $\left(\mathrm{C}_{20} \mathrm{H}_{39} \mathrm{O}\right)$ yang jika terkena air dengan pengaruh enzim klorofilase akan berubah menjadi fitol $\left(\mathrm{C}_{20} \mathrm{H}_{39} \mathrm{OH}\right)$. Fitol adalah alkohol primer jenuh yang mempunyai daya afinitas yang kuat terhadap $\mathrm{O}_{2}$ dalam proses reduksi klorofil. Sifat fisik klorofil adalah menerima dan atau memantulkannya dalam gelombang yang berlainan (berpendar $=$ berfluorescens). Klorofil banyak menyerap sinar dengan panjang gelombang antara 400-700 nm, terutama sinar merah dan biru.

Sifat kimia klorofil antara lain adalah (1) tidak larut dalam air, melainkan larut dalam pelarut organik yang lebih polar, seperti etanol dan kloroform, (2) inti $\mathrm{Mg}$ akan tergeser oleh 2 atom $\mathrm{H}$ bila dalam suasana asam, sehingga membentuk suatu persenyawaan yang disebut feofitin yang berwarna coklat.

\section{Analisis Kandungan Fitokimia Simplisia Daun Sembung}

Uji fitokimia terhadap serbuk simplisia daun sembung baik yang ditanam dengan naungan ataupun tanpa naungan bertujuan untuk mengetahui ada atau tidaknya senyawa metabolit sekunder di dalam simplisia tersebut. Senyawa metabolit sekunder merupakan bahan aktif tanaman yang memiliki banyak sekali potensi sebagai obat. Uji fitokimia me-rupakan uji pendahuluan untuk melan-jutkan ke tahapan uji berikutnya.

Uji fitokimia simplisia dilakukan secara kualitatif dengan menggunakan pereaksi-pereaksi yang spesifik pendeteksi golongan senyawa metabolit sekunder. Berdasarkan Tabel 5, diketahui bahwa kandungan senyawa metabolit sekunder yang terdapat pada simplisia daun sembung baik yang ditanam menggunakan naungan ataupun tanpa naungan menunjukan hasil yang tidak berbeda secara signifikan untuk senyawa flavornoid, saponin, dan glikosida. Sedangkan kandungan alkaloid dan terpenoid pada simplisia daun sembung naungan memberikan hasil uji yang lebih tajam (++) dibandingkan dengan tanpa naungan. 
Tabel 5. Hasil Uji Fitokomia Serbuk Simplisia Daun Sembung

\begin{tabular}{lcc}
\hline \multirow{2}{*}{$\begin{array}{c}\text { Golongan } \\
\text { senyawa } \\
\text { metabolit } \\
\text { sekunder }\end{array}$} & \multicolumn{2}{c}{$\begin{array}{c}\text { Simplisia Daun } \\
\text { Sembung }\end{array}$} \\
\cline { 2 - 3 } & Naungan & $\begin{array}{c}\text { Tanpa } \\
\text { Naungan }\end{array}$ \\
\hline Alkaloid & & ++ \\
- Dragendorff & & + \\
- Mayer & & \\
- bouchardt & & \\
Flavonoid & + & + \\
Saponin & + & + \\
Glikosida & + & + \\
Terpenoid & ++ & + \\
\hline
\end{tabular}

Badan Pengawas Obat dan Makanan membagi pemanfaatan tanaman obat dalam tiga strata, yaitu jamu, obat herbal terstandar, dan fitofarmaka. Jamu dikembangkan dari warisan yang dimiliki masyarakat suku bangsa Indonesia. Strata di atas jamu adalah obat bahan alam atau obat herbal terstandar yang bahan bakunya sudah dalam bentuk ekstrak dan aspek keamanan serta khasiatnya telah teruji pada hewan percobaan yang dikenal sebagai uji praklinik. Strata teratas dalam dalam industri farmasi adalah produk fitofarmaka, dalam bentuk ramuan ekstrak, terutama untuk pelayanan kesehatan formal, dan telah melalui uji klinik di instalasi pelayanan kesehatan formal. Dalam rangka inilah maka dilakukan serangkaian uji fitokimia tersebut di atas, untuk mengetahui kandungan kimia dalam simplisia daun sembung sebagai sumber bahan sediaan obat herbal. Sehingga dapat dilanjutkan pada uji khasiat dan kliniknya.

\section{KESIMPULAN DAN SARAN}

Pertumbuhan tanaman daun sembung antara naungan dan tanpa naungan tidak berbeda nyata secara statistik. Biomassa daun sembung lebih besar pada tanaman tanpa naungan, klorofil lebih tinggi pada tanaman dengan naungan. Secara kualitatif terdapat perbedaan yang kecil dalam kandungan fitokimia tanaman dengan naungan dan tanpa naungan.

Pada penelitian ini disarankan untuk dilakukan uji kandungan fitokimia secara kuantitatif dan uji aktifitas ekstrak daun sembung sebagai bahan fitofarmaka.

\section{DAFTAR PUSTAKA}

Andayani, R., Y. Lisawati, dan Maimunah. 2008. Penentuan Aktivitas Antioksidan, Kadar Fenolat Total dan Likopen Pada Buah Tomat (Solanum lycopersicum L.). Jurnal Sains dan Teknologi Farmasi. Vol 13(1). Departemen Pendidikan Nasional. Jakarta.

Bintang, M. 2010. Biokimia Teknik Penelitian. Erlangga. Jakarta.

Departemen Kesehatan RI. 1980. Materia Medika Indonesia. Jilid IV. Direktorat Jenderal Pengawasan Obat dan Makanan. Jakarta. Hal.92-98.

Departemen Kesehatan RI. 1985. Cara Pembuatan Simplisia. Direktorat Jenderal Pengawasan Obat dan Makanan. Jakarta.

Departemen Kesehatan RI. 2000. Parameter Standar Umum Ekstrak Tumbuhan Obat. Direktorat Jenderal Pengawasan Obat dan Makanan. Jakarta. Hal.9-11.

Departemen Kesehatan RI. 2004. Monograph of Indonesian Medicinal Plant Extracts Volume I. Direktorat Jenderal Pengawasan Obat dan Makanan. Jakarta.

Ghulamahdi, M., Sandra A. Aziz, dan Nirwan. 2008.Peningkatan Laju Pertumbuhan dan 
Kandungan Flavonoid Klon Daun Dewa (Gynura pseudochina (L) DC) melalui Periode Pencahayaan. Bul.Agro.(36)(1)40-48.

Hanani, E. 2012. Standardisasi Tanaman Obat dalam Mendukung Penggunaan Sediaan Obat yang Rasional. Prosiding Simposium Nasional Kimia Bahan Alam XX. Himpunan Kimia Bahan Alam Indonesia.

Harborne. J.B. Diterjemahkan oleh K. Padmawinata. 1987. Metode Fitokimia Penuntun Cara Modern Menganalisis Tumbuhan. Terbitan Kedua. Institut Teknologi Bandung. Bandung.

Helliwel, B dan J.M.C Gutteridge. 1999. Free Radical in Biology and Medicine. $3^{\text {rd }}$ edition. Oxford University. United Kingdom.

Heyne, K. 1987. Tumbuhan Berguna Indonesia Jilid 2. Cetakan 1. Badan Litbang Kehutanan. Jakarta. Hal 622-627.

Khopkar, S.M. Diterjemahkan oleh A. Saptorahardjo. 2003. Konsep Dasar Kimia Analitik. Universitas Indonesia. Jakarta.

Kiswandono, A.A. dan M. Maslahat. 2011. Uji Antioksidan Ekstrak Heksana, Etil Asetat, Etanol, Metanol 80\% dan Air Daun Kelor (Moringa oleifera Lamk.). Jurnal Sains Natural. Vol.1(1) Hal. 39-44. Universitas Nusa Bangsa. Bogor.

Lotulung, P. D. N., S. Fajriah, A. Sundowo, E. Filaila. 2009. Anti Diabetic Flavanone Compound from The Leaves of Artocarpus communis. Indo. J. Chem 9(3), 466-469.

Markham, K.R. Diterjemahkan oleh K. Padmawinata. 1988. Cara Mengidentifikasi Flavonoid. Institut Teknologi Bandung. Bandung.

Maslahat, M., L. Nurhayati, I. Oktafiani. 2012. Potensi Ektrak Etanol 95\% Simplisia daun Sirih Hijau (Piper betle L.) dan Sirih Merah (Piper Cf. fragile Benth) sebagai Antioksidan. Prosiding Simposium Nasional Kimia Bahan Alam XX. Hal 159-172. Himpunan Kimia Bahan Alam Indonesia.

Maslahat, M., H. Luciana, O. Farobi. 2010. Isolasi dan Elusidasi Senyawa Alkaloid pada Biji Mahoni. Poster Ilmiah yang dipresentasikan pada Simposium Nasional Kimia Bahan Alam. Himpunan Kimia Bahan Alam Indonesia. Institut Teknologi Bandung.

Maslahat, M., F. Nurilmala, N. Yuliani, D. Budibruri. 2013. IbM tanaman Obat Antidiabetes bagi Para Petani Desa Cogreg Parung Bogor. Laporan Akhir Program Ipteks bagi Masyarakat (IbM). PS Kimia FMIPA UNB. Bogor.

Muhlisah, F. 2002. Tanaman Obat Keluarga. Cetakan kesembilan. Penebar Swadaya. Jakarta. Hal. 74-76.

Mulja, M. dan Suharman. 1995. Analisis Instrumental. Cetakan Pertama. Universitas Airlangga. Surabaya.

O'neil, MJ. 2002. The Merck Index an Encyclopedia of Chemical, Drugs and Biologicals. $13^{\text {th }}$ 
edition. Merck and Co. Inc. United State of America.

O'neil, M.J., P.E Heckelman, C.B Koch dan K.J Roman. 2006. The Merck Index an Encyclopedia of Chemical, Drugs and Biologicals. $14^{\text {th }}$ edition. Merck and Co. Inc. United State of America.

Pietta, P dan Giorgio Pietta. 2000. Flavonoids as Antioxidants. Journal of Natural Products. Vol. 63(7). American Chemical Society and American Society of Pharmacognosy. United State of America.

Robinson, Trevor. Diterjemahkan oleh K. Padmawinata. 1995. Kandungan Organik Tumbuhan Tinggi. Institut Teknologi Bandung. Bandung.

Sastrohamidjodjo, H. 1995. Sintesis Bahan Alam. Universitas Gajah Mada. Yogyakarta.
Sembiring, B. 2007. Teknologi Penyiapan Simplisia Terstandar Tanaman Obat. Warta Puslitbangbun Vol. 13(2). Balai Penelitian Tanaman Obat dan Aromatik. Bogor.

Siatka, T dan M. Kašparová. 2010. Seasonal Variation in Total Phenolic and Flavonoid Contents and DPPH Scavenging Activity of Bellis perennis L. Flowers. Molecules. Vol.15. University in Prague. Czech Republic.

Sjahid, L.R. 2008. Isolasi dan Identifikasi Flavonoid dari Daun Dewandaru (Eugenia uniflora L.) (Skripsi). Universitas Muhammadiyah Surakarta. Surakarta.

Winarsi, Hery. 2007. Antioksidan Alami dan Radikal Bebas. Kanisius. Yogyakarta. Hal. 11-82. 